\title{
ON THE BIOLOGY OF CALANUS FINMAR- CHICUS. VII. FACTORS AFFECTING EGG PRODUCTION
}

\author{
By S. M. Marshall and A. P. Orr \\ The Marine Station, Millport
}

(Plate I and Text-figs. I-5)

Comparatively little is known about the factors affecting egg-laying in Calanus. Deductions from work in the field have been made by Nicholls (1933 $a, b$ ) and Marshall, Nicholls \& Orr (I934), and experimental work in the laboratory has been done by Raymont \& Gross (I942).

\section{EGG-LAYING IN CALANUS}

The anatomy of the reproductive system has been described in detail by Lowe (1935). In the female there is a pair of diverticula extending from the proximal end of the oviduct into the head region, and into this the developing eggs pass. Each diverticulum has a dorsal and a ventral channel, and the eggs pass from the dorsal into the ventral channel and then into the oviduct proper. The oviduct rises from the forward end of the ovary and crosses the body laterally and ventrally so that a short part of it can be clearly seen.

The state of development of the eggs can be seen in the living Calanus, and four stages have been described by Marshall et al. (1934); these are, early, medium (P1. IA), mature and spent. It has been found convenient to make a further division between the medium and the mature, namely the semi-ripe. In the immature female the ovary is small and in the oviduct there is only one row of small eggs. As the ovary enlarges the two diverticula also enlarge and become filled with eggs. In the medium state the dorsal channels of the diverticula are filled with enlarging eggs, and the eggs in the oviducts also increase in size and number. The diverticula gradually fill up until the whole of the space in the head is full of enlarging eggs; this may be called the semiripe stage. In the mature female (Pl. IB) the most ventral rows of eggs are larger than those in the rest of the diverticula, and similar large eggs are also seen in the oviducts which have now developed secondary pockets projecting towards the body wall (Lowe, 1935). Before laying (sometimes as much as $48 \mathrm{hr}$. before) these large eggs swell still further, become granular in appearance and turn slightly orange-pink in colour. Just before laying the pink colour usually deepens, the nucleus disappears and the eggs are then squeezed out through the genital aperture as a string of roughly pear-shaped masses which separate and round off within a minute or two (P1. ID-F). 
Raymont \& Gross (I942) state that 'the ova which were extremely small in the narrow oviduct were seen to swell almost instantaneously after extrusion to form oval or slightly irregular shaped eggs of very much greater volume; in fact each egg attained a volume greater than that of all the 30-40 eggs inside the oviduct, obviously by a rapid imbibition of water'. Lowndes (I943) also states that whereas the diameter of the largest eggs in the oviducts is $6 \mathrm{I} \cdot 5 \mu$, the diameter of eggs $\mathrm{I} 8 \mathrm{hr}$. after extrusion is I $7 \mathrm{I} \mu$. Pl. Ic, however, shows the oviduct in a ripe Calanus with large eggs almost ready for spawning, and it will be seen that they are much the same size as those being laid (P1. ID). Several other stages in egg-laying are also shown. In a ripe female the pressure in the diverticula and oviducts causes the eggs to assume an irregular shape, often almost square in side view, and it is impossible to measure the volume accurately. Approximate measurements made on about a dozen eggs from several ripe females gave a volume very much the same as the shed eggs. Thus 5 eggs from a single ripe female had volumes ranging from $\mathrm{I} \cdot \mathrm{I} 2 \times 10^{6}$ to $\mathrm{I} \cdot 45 \times 10^{6} \mu^{3}$, whereas the same batch of eggs, when measured after they had been laid about half an hour later, had an average volume of $\mathrm{I} \cdot 59 \times 10^{6} \mu^{3}$ (diameter $\mathrm{I} 45 \mu$ ). It is probable that Lowndes was measuring unripe eggs. The size he gives (I I I $\mu$ diameter) is that of $C$. helgolandicus, which is the predominant form at Plymouth (Russell, I95I). The process of laying a batch of eggs which may consist of anything up to I50 (though usually 20-60) occupies quite a short timeusually under a quarter of an hour and sometimes only a few minutes. In the laboratory a batch of eggs was usually found in one clump which indicates that the Calanus remains passive during the process. After laying, the appearance of the Calanus may go back to the semi-ripe state again if all the large eggs have been extruded.

Occasionally eggs were laid which were abnormal. Sometimes they went opaque at once, sometimes they appeared to have no membrane and at a touch collapsed into a viscous drop of protoplasm; sometimes they extruded part of their substance as a very small droplet. These small spheres were observed by Raymont \& Gross (I942), who took them for newly laid eggs. Occasionally, also, in a batch of eggs one will be twice or three times as large as the rest. These large eggs may begin to develop but never hatch. J. P. Harding's observations (personal communication) suggest that they are diploid or polyploid eggs. After Calanus has been kept in the laboratory for some time the laying of abnormal eggs becomes more frequent.

A number of females were found in which the reproductive organs were in the same state as in the ordinary Stage V. Occasionally a Stage V is seen with a large ovary and well-developed eggs in the diverticula, but as a rule the gonad is very small, no diverticula are visible and the genital ducts are thin cords with no eggs in them. Some of these very immature females may have been newly moulted, but this category also contains the infertile, the 
parasitized and the abnormal. They are often characterized by an unusually marked development of red pigment at the posterior end of the cephalothorax. Thirty-eight of them were kept and fed to see if they would eventually produce eggs, but most of them died without doing so. In some the ovaries became obviously abnormal and in several a nematode became visible in the body cavity after a few days. Twelve reached maturity and laid eggs, one in 7 days, two in 9, one each in 15 and 16 , two in 17 , one each in 18 and 19 and three in 20 days.

In view of Rees's (I949) discovery that two forms of Calanus were present in the North Sea, those in our hauls in the Clyde sea area were examined. It was found that there were usually a few helgolandicus, but the proportion was never more than 5-10\%. In the course of egg-laying experiments it was observed that some females were laying eggs decidedly larger than the

TABle I. Size of EgGS IN CALANUS FINMARCHICUS AND

\section{HELGOLANDICUS}

\begin{tabular}{|c|c|c|c|}
\hline \multicolumn{2}{|c|}{ finmarchicus } & \multicolumn{2}{|c|}{ helgolandicus } \\
\hline Size $(\mu)$ & No. of eggs & Size $(\mu)$ & No. of eggs \\
\hline I38-I 42 & 2 & $159-163$ & $\circ$ \\
\hline $142-146$ & I3 & $163-168$ & I \\
\hline $146-15 \mathrm{I}$ & 8 & $168-172$ & Io \\
\hline I5I-155 & 2 & I $72-176$ & Io \\
\hline $155-159$ & 0 & $176-181$ & 3 \\
\hline & & $181-185$ & I \\
\hline
\end{tabular}

majority, and on examination these females were found to be helgolandicus. The difference in size extends also to the nauplius. The result of a measurement of 25 of each type of egg laid on I4 March 1950 is shown in Table I. There is a certain variation in size even in the eggs laid by finmarchicus, but there is usually a clear difference between the two types. Occasionally, however, eggs of intermediate size were seen and these were laid by finmarchicus. No experiments on interbreeding were made, but Rees has suggested that it may take place and if so an intermediate size of egg might be one result. Of 683 females of the over-wintering stock laying eggs in our experiments $4.1 \%$ were helgolandicus. No helgolandicus were seen among the first generation females.

The Calanus for experiment were usually obtained in the afternoon off Garroch Head at a depth of 50-100 m. in a coarse silk tow-net. They were sorted shortly after capture and the selected females kept singly in small crystallizing dishes of $25 \mathrm{ml}$. capacity. The volume of water used was about $20 \mathrm{ml}$. They were usually kept in ultra-filtered water or ultra-filtered water with culture added. The sea water was collected off Keppel Pier and filtered through a 'Gradocol' membrane of average pore diameter $0.9 \mu$. Calanus kept in this without addition were considered to be starved. The medium was changed every second day and in these conditions the Calanus lived well 
and if suitably fed, sometimes for months. After a long time, those kept in culture tended to develop surface growths in the form of a dense mat of minute unidentified organisms, probably largely bacterial. Sometimes the growth would envelop the whole of the cephalothorax and the Calanus might live like this for some weeks, although it would become very sluggish. Only healthy specimens were used but, when the required type was rare, rigorous selection was not possible and specimens therefore often lacked caudal furcae, or the tips of their antennae, and sometimes lacked spines or even joints on some of the pleopods. They lived well in spite of these injuries and, indeed, it is surprising how much a Calanus will endure.

When set up in small dishes in the evening practically all the 'mature' Calanus had laid by the next morning (see p. 536), although Harding (Harding, Marshall \& Orr, I95I) observed that few mature females fixed during the day contained completely ripe eggs. His criterion of ripeness was the reaching of the full metaphase of the first reduction division, which is the stage reached

Table II. Diurnal Egg Production i9-20 March i95i. TOW-NETting TAKen 4 P.M., I9 MARCH. IO4 CALANUS

\begin{tabular}{|c|c|c|c|c|c|c|c|}
\hline $\begin{array}{l}\text { Time } \\
\text { (hr. } \\
\text { G.M.T.) }\end{array}$ & $\begin{array}{l}\text { No. of } \\
\text { Calanus } \\
\text { laying }\end{array}$ & $\begin{array}{l}\text { Total egg } \\
\text { produc- } \\
\text { tion }\end{array}$ & $\begin{array}{l}\text { Av. no. } \\
\text { eggs/batch }\end{array}$ & $\begin{array}{l}\text { Time } \\
\text { (hr. } \\
\text { G.M.T.) }\end{array}$ & $\begin{array}{l}\text { No. of } \\
\text { Calanus } \\
\text { laying }\end{array}$ & $\begin{array}{l}\text { Total egg } \\
\text { produc- } \\
\text { tion }\end{array}$ & $\begin{array}{l}\text { Av. no. } \\
\text { eggs/batch }\end{array}$ \\
\hline I9 & 0 & 0 & - & 4 & I4. & 583 & $4 I \cdot 6$ \\
\hline 20 & 0 & 0 & - & 5 & $4^{\star}$ & 120 & $40 \cdot 0$ \\
\hline $2 \mathrm{I}$ & 0 & 0 & - & 6 & 2 & 33 & 16.5 \\
\hline 22 & 0 & 0 & - & 7 & I & 28 & 28.0 \\
\hline 23 & I & 36 & $36 \cdot 0$ & 9 & 2 & 70 & 35.0 \\
\hline 24 & 2 & 79 & $40 \cdot 0$ & 12 & 0 & 0 & - \\
\hline I & $24^{\star}$ & 817 & $37 \cdot I$ & I5 & 0 & 0 & - \\
\hline 2 & $27^{\star}$ & II 65 & $44 \cdot 8$ & I8 & 0 & 0 & - \\
\hline 3 & 20 & 9 II & 43.4 & $2 I$ & I & I5 & I 5.0 \\
\hline
\end{tabular}

when the eggs are laid. It was therefore decided to examine Calanus hourly to see if there was a restricted time for egg-laying. One hundred and four ripe female Calanus picked out from a tow-netting taken at 4 p.m. off Garroch Head between 50 and $100 \mathrm{~m}$. (with 75 fathoms of warp out) were set up about 6 p.m. each in a separate dish of ultra-filtered sea water. They were kept in a cool aquarium and examined at hourly intervals throughout the night. No attempt was made to keep them entirely in the dark. The production of eggs is shown in Table II. Only three had spawned by midnight, $68 \%$ spawned between $\mathrm{I} 2$ midnight and 3 a.m. and most of the remainder before 4 o'clock. Of the total only five did not lay. The number of eggs laid per Calanus was remarkably constant, the average being about 40.

These rather surprising results might have been caused by the disturbance of capture and examination or else, since they were caught at a considerable depth, by the sudden decrease in pressure. Another tow-netting was there- 
fore taken at the same place but slightly nearer the surface (with only 50 fathoms of warp out) at 4 a.m., fifty ripe females were picked out into separate dishes and these were examined every $3 \mathrm{hr}$. Although a smaller total number of eggs was laid and the peak of production was not so marked, spawning again took place mainly during the early morning (Table III). Thirteen of the fifty did not lay. The smaller number of eggs laid may be caused by the longer period of starvation in ultra-filtered water. It will be shown later (see Table VI) that starvation may have a marked effect on egg production even as early as the second day.

Each Calanus was discarded after it had laid unless the number of eggs was very small. Several laid small numbers in consecutive hours (e.g. $6+8+$ Io and $5+\mathrm{I} 8$ ), but one laid 28 and 34 with an interval of $\mathrm{I} 8 \mathrm{hr}$. between. The great majority, however, are unlikely to have laid again before the following night.

Table III. Diurnal Egg Production 20-2i March I95I. Tow-NetTing taken 4 A.M., 20 March. Fifty CALANUS

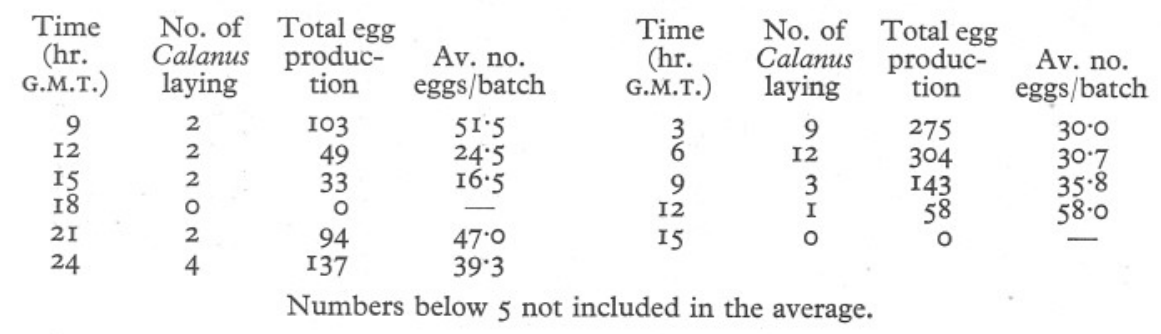

In an experiment in February I950 on the feeding of Calanus throughout $24 \mathrm{hr}$., six out of ten unselected females laid as follows: one between midnight and 2 a.m., four between 2 and 4 a.m. and one between 4 and 6 a.m., thus confirming the more detailed experiments of 195I. Mesopodopsis and Squilla have also been found to lay only during the night (Nair, I939, I94I).

In the Clyde sea area Calanus of the first generation are found close to the surface in May (Marshall et al., I934), and since this change of habit may make a difference in their egg-laying behaviour a similar experiment was done on 30 April to I May I95I when the first generation had reached maturity. The results are shown in Table IV, and it will be seen that in contrast to the overwintering stock this generation laid throughout the $24 \mathrm{hr}$. Some Calanus are found also in deep water at this time, and the experiment was repeated using fifty ripe females from deep water (below $50 \mathrm{~m}$.) and fifty from the top $2 \mathrm{~m}$. Both lots behaved in the same way, laying throughout the $24 \mathrm{hr}$.

Another difference between the winter and the first-generation females is that far more $(29 \%)$ of the May females laid second batches of eggs within $24 \mathrm{hr}$. and five even laid a third batch. The average number of eggs laid in the first batch was $6 \mathrm{I} \cdot 3$, in the second $4 \mathrm{I} \cdot 7$, and in the third $28 \cdot 0$. In the majority 
the second batch was laid within IO-I5 hr. after the first. This difference may have been caused by the fact that during May the sea was very rich in diatoms.

In 1950 , to find the total number of eggs which can be produced by a female, those carrying spermatophores (which, since fertilization takes place soon after moulting, may be assumed not to have laid any eggs) were kept in separate dishes in a refrigerator at about $5^{\circ} \mathrm{C}$., fed regularly and examined daily. In all of them the spermatophore was lost after the first day or two. One or two laid also within the first day or two, and, since females normally take a week or two to mature the eggs, these must have been fertilized late when the eggs were almost mature. Most remained for I or 2 weeks without laying. This in itself

Table IV. Diurnal Egg Production 30 April-i May i95I. Tow-NETTING TAKEN II A.M. NINETY-NINE CALANUS

\begin{tabular}{|c|c|c|c|c|c|c|c|}
\hline $\begin{array}{l}\text { Time } \\
\text { (hr. } \\
\text { G.M.T.) }\end{array}$ & $\begin{array}{l}\text { No. of } \\
\text { Calanus } \\
\text { laying }\end{array}$ & $\begin{array}{l}\text { Total egg } \\
\text { produc- } \\
\text { tion }\end{array}$ & $\begin{array}{l}\text { Av. no. } \\
\text { eggs/batch }\end{array}$ & $\begin{array}{l}\text { Time } \\
\text { (hr. } \\
\text { G.M.T.) }\end{array}$ & $\begin{array}{l}\text { No. of } \\
\text { Calanus } \\
\text { laying }\end{array}$ & $\begin{array}{l}\text { Total egg } \\
\text { produc- } \\
\text { tion }\end{array}$ & $\begin{array}{l}\text { Av. no. } \\
\text { eggs/batch }\end{array}$ \\
\hline I5 & I5 & 916 & $6 \mathrm{I} \cdot \mathrm{I}$ & 3 & 0 & 0 & - \\
\hline I6 & 6 & 387 & 64.5 & 4 & 0 & 0 & - \\
\hline I 7 & I & 78 & $78 \cdot 0$ & 5 & 4 & 307 & $76 \cdot 8$ \\
\hline I8 & I4 & $88 \mathrm{I}$ & 62.9 & 6 & 2 & 93 & 46.5 \\
\hline I9 & 6 & 373 & $62 \cdot 2$ & 7 & 0 & 0 & - \\
\hline 20 & 6 & 430 & $71 \cdot 7$ & 9 & 4 & 240 & $60 \cdot 0$ \\
\hline $2 \mathrm{I}$ & 8 & 512 & 64.0 & IO & 3 & I44 & 63.0 \\
\hline 22 & 6 & 406 & $67 \cdot 7$ & I I & 3 & $2 \mathrm{II}$ & $70 \cdot 3$ \\
\hline 23 & 5 & 340 & 68.0 & I3 & 2 & 129 & 62.5 \\
\hline 24 & 2 & 69 & 34.5 & I4 & 2 & II 8 & 59.0 \\
\hline I & 3 & 162 & $54^{\circ} \circ$ & 15 & 0 & 0 & - \\
\hline 2 & 2 & 109 & 54.5 & 16 & 0 & 0 & - \\
\hline
\end{tabular}

was a disadvantage, for conditions in the laboratory were presumably not so healthy as in the sea. From June onwards, therefore, to avoid delay in egg production, they were kept in an aquarium room at a temperature of about I $6^{\circ} \mathrm{C}$.

The results given by those which laid most are shown in Text-fig. I. The majority laid several hundred eggs over periods up to 80 days. The most prolific was brought in on I6 June, laid 586 eggs over a period of 74 days and was still alive on the $93 \mathrm{rd}$ day. From the diagram it is readily seen that egg production often takes place in a series of bursts lasting about a week. These bursts tend to occur at intervals of about 2 weeks and it seemed possible that they might be related to the phases of the moon. In some of the Calanus the egg-laying periods do seem to begin 2 or 3 days after new and full moon, but in others no relation can be made out. The number laid each day varies from I up to about 70 , but after about the 40th day the numbers both of eggs and of days on which laying occurs decrease. The eggs were usually kept for a day or two and, although at the beginning they were all normal and produced healthy nauplii, as the experiment went on the number of abnormal or unhealthy eggs increased. However, eggs produced after as much as 68 days 
in the laboratory did hatch, showing that one fertilization is enough for the whole period of egg production by a female.

It is of course impossible to say how far this pattern is natural for the sea. In the laboratory they had a continuous ample supply of food, whereas in the

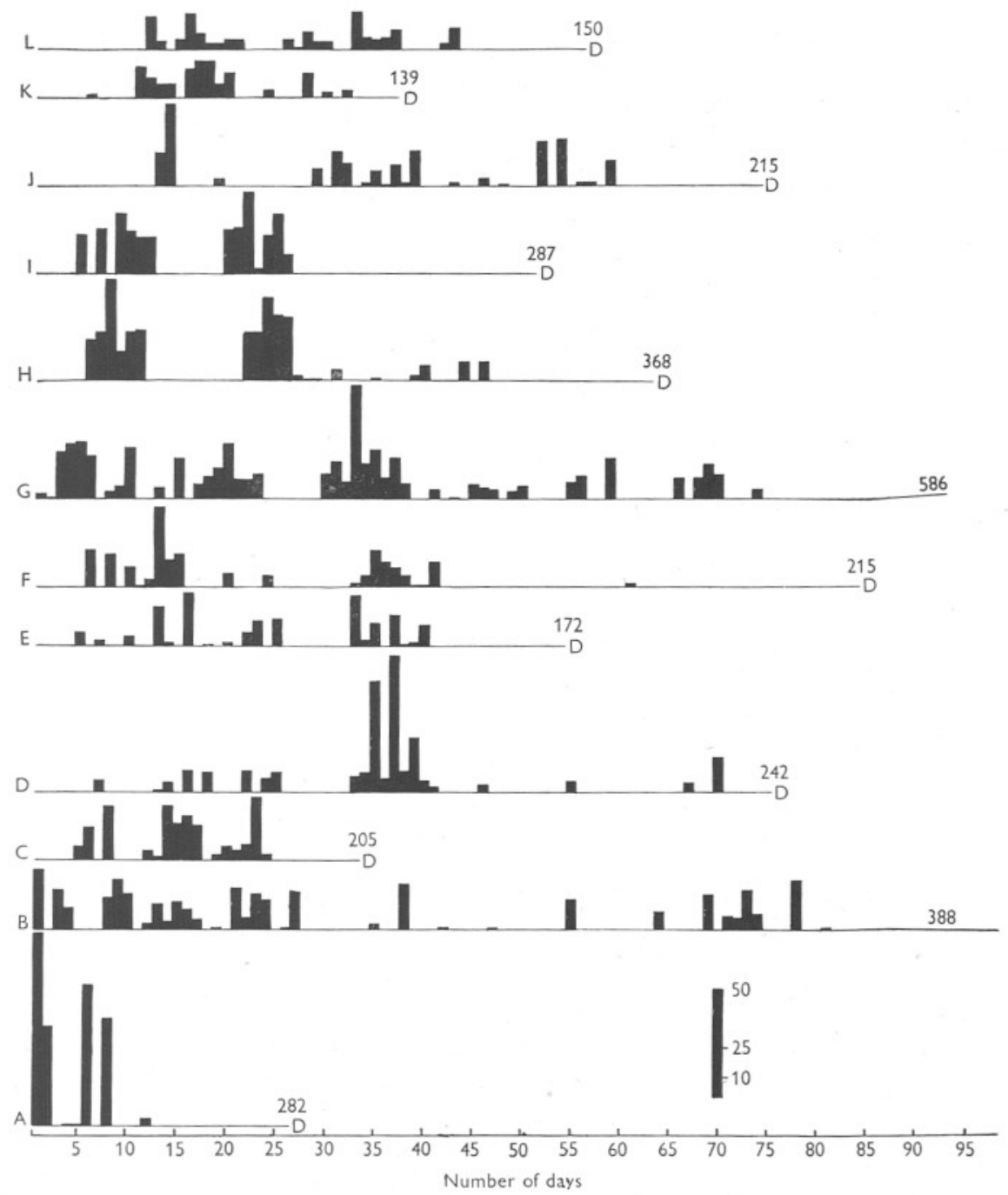

Text-fig. I. Total number of eggs laid by individual Calanus. A: 5. v. 50; B: 13. vi. 50; C-F: I5. vi. 50; G: I6. vi. 50; H, I: 27. vi. 50; J: 7. vii. 50; K, L: 26. vii. 50.

sea the amount would be much less and probably sporadic (see, however, p. 543). In the sea, on the other hand, Calanus has many enemies at each stage, and few females will survive to lay all their eggs. 


\section{The EfFect of Food on EgG-LAYING}

Many workers have discussed the connexion between maxima of phytoplankton and zooplankton. Marshall et al. (1934) suggested that broods of C. finmarchicus depended for their survival on the presence of diatoms at the time the young brood was growing up. Wimpenny (I937) concluded that phytoplankton-rich water served as a breeding and nursery ground, although adults apparently avoided it. Ussing (1938) showed that in East Greenland, where there is only one diatom increase in the year, copepod reproduction was entirely dependent on it. More recently Wiborg (1940) found a possible connexion between spawning of Calanus and an abundant phytoplankton.

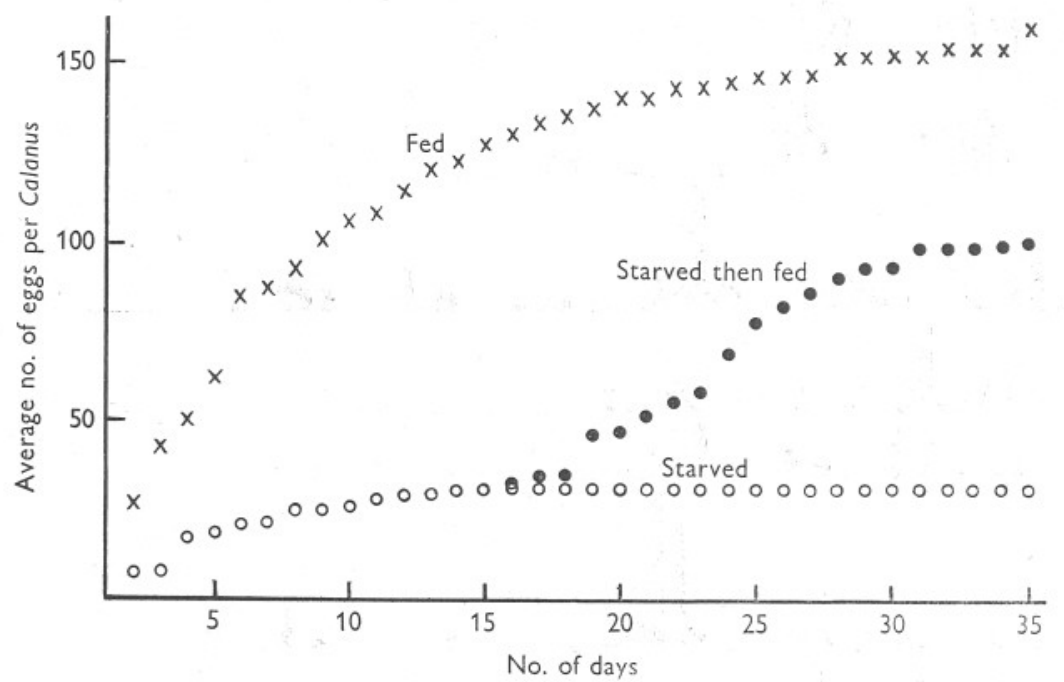

Text-fig. 2. Egg-laying in starved and fed Calanus.

During 1950 and I95I, when females were laying eggs freely, it was thought of interest to see whether they would lay better when fed than when starved. A number (thirty-two) of female Calanus were taken from the sea at the end of April 1950, put singly into the usual small dishes and examined daily for egg production. To avoid the effect of fluctuating temperature they were kept in a refrigerator at about $5^{\circ} \mathrm{C}$. Half were starved by keeping them in ultrafiltered sea water and half were kept in ultra-filtered sea water enriched by Chlamydomonas. The experiment lasted for 35 days, but after 15 days the starved Calanus were divided into two lots; seven of them were now fed and the remaining six continued starved. After the 3oth day conditions deteriorated rapidly, and the majority of the Calanus died. At the end only four survived in the fed, four in the starved then fed, and two in those starved all the time. The results are given in Text-fig. 2, where the total number of eggs laid per living Calanus is shown. There was a large production of eggs on the first and 
second days, and for reasons stated later (p. 536) these have been ignored in the calculations. Thereafter the production of eggs by the fed was always greater than that by the starved; indeed after a week few of the starved were laying at all. The production of eggs in the fed Calanus fell away considerably after 2 weeks, and after the 25 th day only two of them were still laying. The average number of eggs produced per fed Calanus (ignoring the first 2 days) was I09.8. In the starved Calanus it was 23.7 , and only one egg was produced after the division into two batches on the I5th day. On the other hand, the starved Calanus which were given food produced a total of 92.6 eggs per Calanus of which 69.0 were laid after they were fed. Thus, in spite of the deteriorating conditions, feeding the starved Calanus resulted in an egg production not much below that of those fed all the time. It looks as if the eggs had been retained until feeding conditions were favourable.

A similar experiment lasting 36 days and giving similar results was done at the same time, keeping however three Calanus in each of twenty larger dishes which held about $50 \mathrm{ml}$. of water. In this the average number of eggs per Calanus was: in the fed 106.5; in the starved $20 . \mathrm{I}$ (only three per Calanus were laid after the I5th day when the starved were divided into two lots as before); in the starved and then fed, I $7 \cdot$ I before and 40.2 after feeding. The condition of the gonads was examined at the end of this experiment. In the fed the majority still had large eggs in the oviducts, although in one or two the ducts had shrunk. In the starved all had shrunken oviducts, but in those starved then fed all except one had large eggs.

These two experiments were made with females which may or may not have laid before they were caught. One or two indeed, which did not lay during the experiment, may already have completed their egg-laying, and this may account for the smaller total numbers laid when compared with the females of Text-fig. I.

One interesting fact is that even the starved Calanus retained fat up to the end of the experiment. Most Calanus have a store of fat (Lowe, I935) in a sac which lies along the gut. Sometimes, especially in Stage V, this is a large bolster-like mass, sometimes only a small globule restricted to the hind end of the gut. Female Calanus on the whole carry less fat than Stage V, that in the anterior part of the sac usually disappearing gradually as the eggs develop. When mature, however, and under starvation conditions, the fat evidently does not go towards making more eggs but is retained by the animal.

The effect on egg-laying of food in general and of different kinds of food was investigated. The following organisms were used: Coscinodiscus centralis Ehrenberg, Lauderia borealis Gran, Skeletonema costatum (Greville), Rhizosolenia delicatula Cleve, Ditylum brightwelli (West.), Chlamydomonas sp. (Dr Parke's Chlamydomonas I), Hemiselmis rufescens Parke, Dicrateria inornata Parke, Syracosphaera carterae Braarud, Gymnodinium sp., Peridinium trochoideum (Stein) Lemm., and Chlorella stigmatophora Butcher. 
As a standard food a culture of Chlamydomonas was used; some animals were also starved in ultra-filtered sea water.

In January and part of February I95I the females obtained were almost all immature or medium stage and these were used for feeding experiments. Apart from a few specimens (which were probably wrongly diagnosed as immature) most of the immature when fed did not lay until about the $4^{\text {th }}$ day, after which egg production gradually increased. The starved laid no eggs at all.

In a typical experiment lasting from 9 to $\mathrm{I} 6$ February the egg production of twenty immature Calanus was I7, 0, 0, 69, I44, I4I, I79 on successive days, whereas twenty starved produced no eggs over the same period.

A number of experiments were also done about the same time on mediumstage and semi-ripe Calanus. These probably included quite a range of degrees of ripeness. Usually one or two laid eggs on the first day, and the number of eggs and of laying females increased from then on. In a typical experiment lasting for 7 days the egg production by twenty fed Calanus on successive days was $26,72, \mathrm{I} 49, \mathrm{I} 93, \mathrm{I} 78, \mathrm{I} 55$ and 66 , a total of 839 . In twenty starved it was 26, I7, 2, I9, I3, I, I4, a total of 92 .

From the middle of February onwards, ripe females became more abundant and were used for a long series of experiments using different kinds of food.

On the morning after an experiment had been set up there was always a large number of eggs in nearly all the dishes whether the Calanus had been fed or not. Apparently the shock of capture and examination stimulates a ripe female to lay. The first day's results are therefore not taken into account in the calculations of the average numbers produced with different foods. The great majority of the Calanus in the experiments did lay some eggs, and those which were given suitable food both laid more often and produced more eggs than the starved. Some of the cultures used as food were as good as Chlamydomonas, and in others the Calanus produced no more eggs than when starved. The organisms are of different size and no attempt was made to equate the volume of food given, but the concentration was always very much richer than anything the Calanus would find under natural conditions.

Table V shows a typical experiment comparing the eggs produced by Calanus fed on Chlamydomonas, Hemiselmis, Syracosphaera and Ditylum with starved Calanus. It is apparent that (omitting egg production on the first day) Ditylum, Chlamydomonas and Syracosphaera are all effective foods, whereas giving Hemiselmis is little better than starvation. In it they produced fewer faecal pellets than with Chlamydomonas. With the starved Calanus only one or two faecal pellets were produced and these were very small and almost transparent. With Chlamydomonas they were well compacted and dark, with Ditylum (as with all diatoms tested) and with Syracosphaera they were larger and paler. 
It will be seen that there are individual variations in the Calanus and that with suitable food some lay every day and some most days. Raymont \& Gross (I942) assumed that when a Calanus laid on two successive days, one period of egg-laying had been interrupted. Table V and Text-fig. I show, however, that with suitable food laying on several days running is quite normal (see also p. 532). The batches laid on succeeding days are often quite large but

\section{Table V. Egg Production in Individual CaLANUS using Different} FOODS. 22-29 MARCH I95I

(Experiments run simultaneously with fifteen animals in most.)

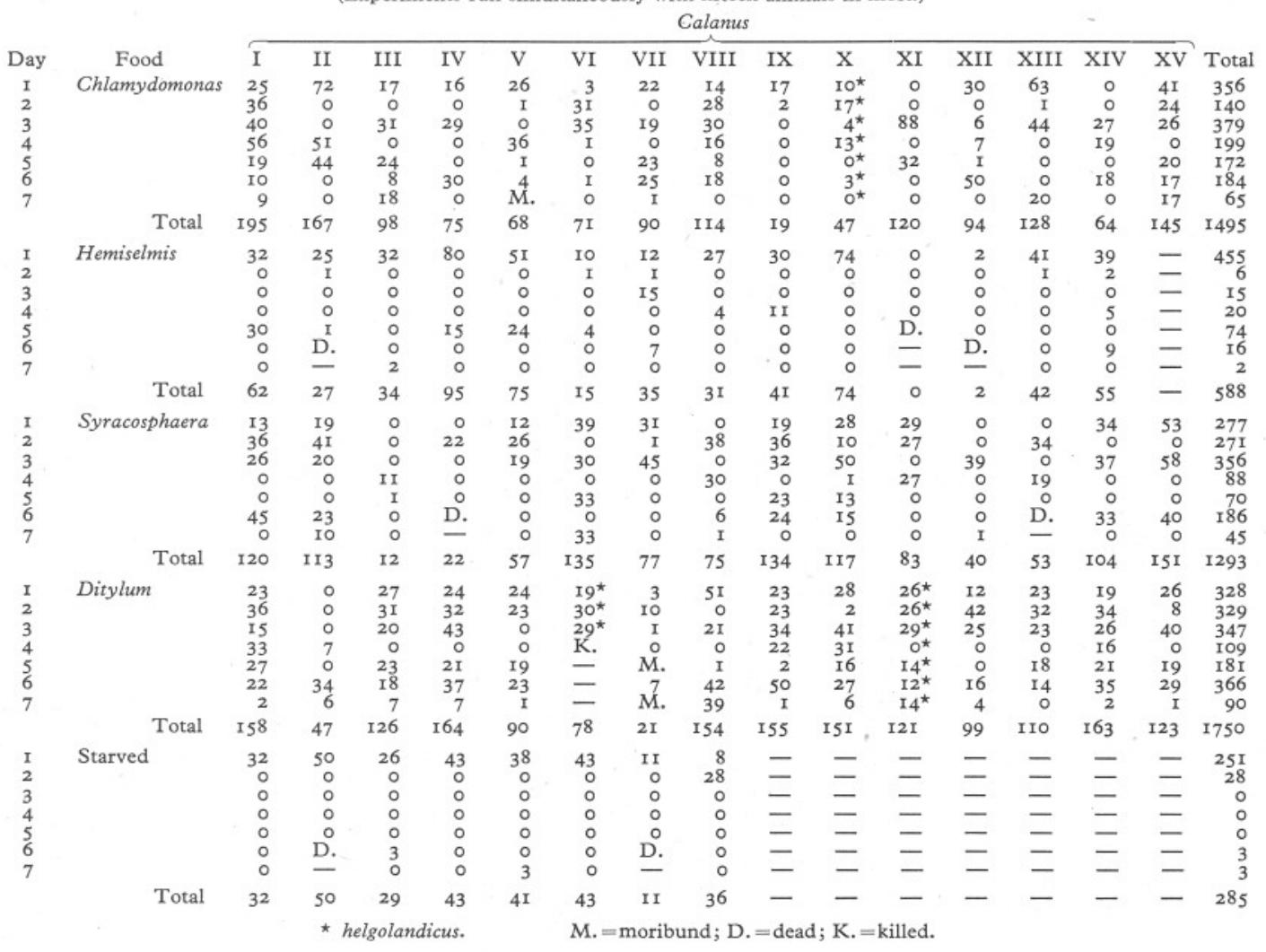

occasionally a small number appears, often only one or two. A number of eggs ripen together in the oviduct, but possibly for some reason they are not all laid at once and the few remaining are extruded later. For this reason numbers under five are omitted in calculating the number per batch.

Table VI shows the summarized results of all feeding experiments.

In a culture of Chlorella as rich as the Chlamydomonas used, the egg production was extremely low, even lower than in the starved. The faecal pellets 


\section{Table VI. Comparison of the Effect of Different Foods on Egg Production}

\begin{tabular}{|c|c|c|c|c|c|c|c|c|c|c|c|c|c|}
\hline \multirow[b]{3}{*}{ Date begun } & \multirow{3}{*}{$\begin{array}{l}\text { No. of } \\
\text { Calanus }\end{array}$} & \multirow[b]{3}{*}{ Food } & & & & & & & & \multicolumn{4}{|c|}{ Omitting first day } \\
\hline & & & \multicolumn{7}{|c|}{ Total no. of eggs laid on day } & \multirow{2}{*}{$\begin{array}{l}\text { No. } \\
\text { laying }\end{array}$} & \multirow{2}{*}{$\begin{array}{l}\text { Total no. } \\
\text { of eggs }\end{array}$} & \multirow{2}{*}{$\begin{array}{c}\text { Eggs per } \\
\text { batch» }\end{array}$} & \multirow{2}{*}{$\begin{array}{c}\text { Eggs per } \\
\text { Calanus } \\
\text { per day }\end{array}$} \\
\hline & & & I & 2 & 3 & 4 & 5 & 6 & 7 & & & & \\
\hline 29. i. 5 I & $\begin{array}{r}\text { II } \\
8\end{array}$ & $\begin{array}{l}\text { Chlamydomonas } \\
\text { Starved }\end{array}$ & $\begin{array}{r}49 \\
146\end{array}$ & $\begin{array}{r}28 \\
4\end{array}$ & $\begin{array}{r}140 \\
0\end{array}$ & $\begin{array}{l}76 \\
17\end{array}$ & $\begin{array}{r}157 \\
9\end{array}$ & 二 & $=$ & $\begin{array}{l}9 \\
3\end{array}$ & $\begin{array}{r}40 \mathrm{I} \\
30\end{array}$ & $\begin{array}{l}20 \cdot 4 \\
12 \cdot 5\end{array}$ & $\begin{array}{l}9 \cdot 1 \\
0 \cdot 9\end{array}$ \\
\hline 2I. ii. $5 \mathrm{I}$ & $\begin{array}{l}20 \\
20\end{array}$ & $\begin{array}{l}\text { Chlamydomonas } \\
\text { Starved }\end{array}$ & $\begin{array}{l}245 \\
266\end{array}$ & $\begin{array}{l}66 \\
32\end{array}$ & $\begin{array}{r}189 \\
17\end{array}$ & $\begin{array}{r}203 \\
15\end{array}$ & $\begin{array}{r}304 \\
0\end{array}$ & $\begin{array}{r}77 \\
\circ\end{array}$ & 二 & $\begin{array}{r}18 \\
6\end{array}$ & $\begin{array}{r}839 \\
64\end{array}$ & $\begin{array}{l}21 \cdot 4 \\
12 \cdot 4\end{array}$ & $\begin{array}{l}8 \cdot 8 \\
0.8\end{array}$ \\
\hline 27. ii. $5 \mathrm{I}$ & $\begin{array}{l}\text { I5 } \\
15 \\
15 \\
15\end{array}$ & $\begin{array}{l}\text { Chlamydomonas } \\
\text { Coscinodiscus } \\
\text { Skeletonema } \\
\text { Starved }\end{array}$ & $\begin{array}{l}312 \\
258 \\
217 \\
236\end{array}$ & $\begin{array}{r}\mathrm{I} 74 \\
17 \\
\mathrm{I} 42 \\
32\end{array}$ & $\begin{array}{r}375 \\
74 \\
177 \\
3\end{array}$ & $\begin{array}{r}214 \\
35 \\
97 \\
0\end{array}$ & $\begin{array}{r}177 \\
26 \\
231 \\
11\end{array}$ & $\begin{array}{r}105 \\
53 \\
\text { I13 } \\
31\end{array}$ & $\begin{array}{r}138 \\
56 \\
27 \\
7\end{array}$ & $\begin{array}{r}14 \\
13 \\
14 \\
9\end{array}$ & $\begin{array}{r}1183 \\
261 \\
787 \\
84\end{array}$ & $\begin{array}{r}23.0 \\
11 \cdot 5 \\
19 \cdot 5 \\
8.9\end{array}$ & $\begin{array}{r}\text { I5.4 } \\
3.0 \\
9.4 \\
1.0\end{array}$ \\
\hline 6. iii. $5 \mathrm{I}$ & $\begin{array}{l}15 \\
15 \\
15 \\
8\end{array}$ & $\begin{array}{l}\text { Chlamydomonas } \\
\text { Peridinium } \\
\text { Rhizosolenia } \\
\text { Starved }\end{array}$ & $\begin{array}{l}169 \dagger \\
331 \dagger \\
514 \\
63 \dagger\end{array}$ & $\begin{array}{r}406 \\
132 \\
195 \\
49\end{array}$ & $\begin{array}{r}358 \\
313 \\
98 \\
32\end{array}$ & $\begin{array}{r}230 \\
86 \\
51 \\
0\end{array}$ & $\begin{array}{r}70 \\
213 \\
69 \\
0\end{array}$ & $\begin{array}{r}82 \\
\text { III } \\
50 \\
\text { I }\end{array}$ & 二 & $\begin{array}{r}14 \\
15 \\
12 \\
5\end{array}$ & $\begin{array}{r}1146 \\
865 \\
463 \\
81\end{array}$ & $\begin{array}{l}29 \cdot 0 \\
24 \cdot 8 \\
22 \cdot 6 \\
15 \cdot 4\end{array}$ & $\begin{array}{r}16 \cdot 4 \\
\text { II.5 } \\
6 \cdot 6 \\
2 \cdot 3\end{array}$ \\
\hline I2. iii. $5 \mathrm{I}$ & $\begin{array}{l}\text { I5 } \\
\text { 15 } \\
15 \\
15 \\
8\end{array}$ & $\begin{array}{l}\text { Chlamydomonas } \\
\text { Dicrateria } \\
\text { Chlorella } \\
\text { Indian Ink } \\
\text { Starved }\end{array}$ & $\begin{array}{l}58 \mathrm{I} \\
547 \\
639 \\
359 \\
208\end{array}$ & $\begin{array}{r}204 \\
16 \\
63 \\
48 \\
50\end{array}$ & $\begin{array}{r}555 \\
\mathrm{I} \\
\mathrm{I} \\
38 \\
3\end{array}$ & $\begin{array}{r}309 \\
102 \\
0 \\
42 \\
2\end{array}$ & $\begin{array}{r}279 \\
37 \\
0 \\
4 \\
28\end{array}$ & $\begin{array}{r}\mathrm{I} 42 \\
26 \\
5 \\
\mathrm{I} 4 \\
0\end{array}$ & $\begin{array}{r}77 \\
18 \\
2 \\
12 \\
22\end{array}$ & $\begin{array}{r}15 \\
\text { II } \\
7 \\
11 \\
11 \\
6\end{array}$ & $\begin{array}{r}1566 \\
200 \\
71 \\
158 \\
105\end{array}$ & $\begin{array}{l}30 \cdot 5 \\
16 \cdot 8 \\
15 \cdot 3 \\
16 \cdot 3 \\
19 \cdot 8\end{array}$ & $\begin{array}{r}17 \cdot 4 \\
2 \cdot 5 \\
0.8 \\
1 \cdot 8 \\
2 \cdot 2\end{array}$ \\
\hline 22. iii. $5 \mathrm{I}$ & $\begin{array}{r}15 \\
13 \\
15 \\
15 \\
8\end{array}$ & $\begin{array}{l}\text { Chlamydomonas } \\
\text { Hemiselmis } \\
\text { Syracosphaera } \\
\text { Ditylum } \\
\text { Starved }\end{array}$ & $\begin{array}{l}356 \\
455 \\
277 \\
328 \\
251\end{array}$ & $\begin{array}{r}140 \\
6 \\
271 \\
329 \\
28\end{array}$ & $\begin{array}{r}379 \\
15 \\
356 \\
347 \\
0\end{array}$ & $\begin{array}{r}199 \\
20 \\
88 \\
109 \\
0\end{array}$ & $\begin{array}{r}172 \\
74 \\
70 \\
181 \\
0\end{array}$ & $\begin{array}{r}184 \\
16 \\
186 \\
366 \\
3\end{array}$ & $\begin{array}{r}65 \\
2 \\
45 \\
90 \\
3\end{array}$ & $\begin{array}{r}15 \\
10 \\
15 \\
15 \\
2\end{array}$ & $\begin{array}{r}1139 \\
133 \\
1016 \\
\text { I422 } \\
34\end{array}$ & $\begin{array}{l}26 \cdot 6 \\
14 \cdot 5 \\
28 \cdot 9 \\
24 \cdot 2 \\
28 \cdot 0\end{array}$ & $\begin{array}{r}\mathrm{I} 2 \cdot 8 \\
\mathrm{I} \cdot 7 \\
\mathrm{II} \cdot 8 \\
\mathrm{I} 6 \cdot 7 \\
0 \cdot 8\end{array}$ \\
\hline 23. iv. 5 I & $\begin{array}{l}\text { I3 } \\
\text { I5 } \\
\text { I5 } \\
\text { II }\end{array}$ & $\begin{array}{l}\text { Chlamydomonas } \\
\text { Lauderia } \\
\text { Gymnodinium } \\
\text { Starved }\end{array}$ & $\begin{array}{l}31 \mathrm{II} \\
58 \mathrm{I} \\
4 \mathrm{I} 7 \\
209\end{array}$ & $\begin{array}{r}479 \\
477 \\
224 \\
35\end{array}$ & $\begin{array}{r}310 \\
103 \\
346 \\
59\end{array}$ & $\begin{array}{r}204 \\
105 \\
224 \\
32\end{array}$ & $\begin{array}{r}337 \\
207 \\
256 \\
39\end{array}$ & $\begin{array}{r}\text { I } 4 \mathrm{I} \\
437 \\
540 \\
0\end{array}$ & $\begin{array}{r}78 \\
450 \\
384 \\
17\end{array}$ & $\begin{array}{r}13 \\
15 \\
15 \\
7\end{array}$ & $\begin{array}{r}1549 \\
1779 \\
1974 \\
182\end{array}$ & $\begin{array}{l}32 \cdot 1 \\
33 \cdot 4 \\
29 \cdot 9 \\
16 \cdot 2\end{array}$ & $\begin{array}{r}20 \cdot 7 \\
2 \mathrm{I} \cdot 2 \\
2 \mathrm{I} \cdot 9 \\
2 \cdot 8\end{array}$ \\
\hline
\end{tabular}

* Numbers below 5 omitted.

† Those of Chlamydomonas and 'starved' and three of those with Peridinium had been in the laboratory overnight and had probably laid their first batch of eggs. 
consisted of a mass of Chlorella cells apparently unchanged. Dicrateria and, as already mentioned, Hemiselmis were both used but neither was a good food. The coccolithophore Syracosphaera was readily taken and egg production was high. This was true also of the dinoflagellate Peridinium trochoideum. The five diatom species used all gave a positive result, although some were apparently better than others. Production in Coscinodiscus, for instance, was only a little higher than in the starved, but the cells were large and lay almost entirely on the bottom of the dish where they may not have been so readily available. Only Peridinium trochoideum, Gymnodinium, Syracosphaera, Ditylum and Lauderia were as good as Chlamydomonas, although Skeletonema (whose cells were mostly on the bottom) was nearly as good.

One inert substance was used, a very dilute suspension of Indian ink. With this the Calanus produced faeces, but the egg production was no higher than in the starved. Thus egg-laying is not caused by the mere passage of material through the gut. In order to test whether the high $\mathrm{pH}$ value or some other factor accompanying a phytoplankton increase had any effect, female Calanus were kept in sea water whose $\mathrm{pH}$ value had been raised to about $8 \cdot 2$, and also in sea water to which cell-free filtrate from a rich Chlamydomonas culture had been added. Neither showed any effect on egg production.

The results show that even although they may be freely taken into the gut, not all the organisms available in the sea are of equal value for egg production. If, as seems probable, the food taken is used in the formation of the eggs laid, then its metabolism must be very rapid. The experiments suggest that egg production by ripe Calanus can be used to test the nutritive value of different - food organisms. It is a simpler and quicker method than feeding copepodites through one or more moults, during which development may also be affected by factors other than food.

An attempt was made to measure the relation between increase in food and increase in egg production. The Calanus were kept in Chlamydomonas cultures varying in concentration from 0 to about 250 cells $/ \mathrm{mm}^{3}$ and the medium changed every other day. The results are shown in Table VII and Text-figs. 3 and 4 . With concentrations as low as $7-8$ cells $/ \mathrm{mm}^{3}$, the egg production is practically the same as with the starved Calanus. It then increases rapidly with increase in food up to about 40 cells $/ \mathrm{mm} .^{3}$, after which the curve flattens off. Although in the richer concentrations some of the Chlamydomonas cells sank to the bottom and were thus less available, it may be concluded that beyond a certain point more food will not lead to greater egg production. If a Chlamydomonas cell is considered to be of equal food value to a Skeletonema cell (being of about equal size), the lowest figures which gave an increase in egg production are less than those of a normal spring diatom increase in the Clyde sea area.

Some experiments in the spring of I950 had suggested that the presence of food might act as a trigger to set off egg-laying. This was not confirmed in 
Table ViI. Effect on Egg Production of Feeding with Increasing Concentration of Culture. 3-io May i95i

$\begin{array}{cc}\text { No. of } & \begin{array}{c}\text { Strength of } \\ \text { culture } \\ \text { Calanus } \\ \text { (cells } / \mathrm{mm} .^{3} \text { ) }\end{array} \\ \text { I5 } & 200-250 \\ \text { I5 } & 70-80 \\ \text { I5 } & 34-40 \\ \text { I5 } & \text { I4-16 } \\ \text { I5 } & 7-8 \\ \text { I5 } & 0\end{array}$

\begin{tabular}{cc} 
& Total no. \\
\hline 2 & 3 \\
$38 \cdot 3$ & $74 \cdot 2$ \\
$38 \cdot 7$ & $61 \cdot 9$ \\
$36 \cdot 0$ & $6 I \cdot 5$ \\
$23 \cdot 5$ & $31 \cdot 4$ \\
13.9 & $19 \cdot 8$ \\
$12 \cdot 9$ & $19 \cdot 6$
\end{tabular}

\begin{tabular}{|c|c|c|c|}
\hline 4 & 5 & 6 & 7 \\
\hline $95 \cdot 7$ & 108.5 & I I $7^{\circ} \mathrm{O}$ & II 9.4 \\
\hline 83.5 & $93^{\circ} \mathrm{I}$ & $98 \cdot 9$ & 106.5 \\
\hline $7 \mathrm{I} \cdot 2$ & 82.4 & $87 \cdot I$ & $88 \cdot 7$ \\
\hline $37 \cdot 8$ & 39.5 & $40 \cdot 8$ & $42 \cdot 2$ \\
\hline $2 \mathrm{I} \cdot 7$ & $24 \cdot I$ & 25.9 & $26 \cdot 4$ \\
\hline I9.7 & $2 \mathrm{I} \cdot 4$ & $2 \mathrm{I} \cdot 4$ & $2 I \cdot 5$ \\
\hline
\end{tabular}

\begin{tabular}{|c|c|c|}
\hline \multicolumn{3}{|c|}{ Omitting first day } \\
\hline $\begin{array}{l}\text { No. } \\
\text { laying }\end{array}$ & $\begin{array}{l}\text { No. of } \\
\text { eggs per } \\
\text { batch }\end{array}$ & $\begin{array}{l}\text { Eggs per } \\
\text { Calanus } \\
\text { per day }\end{array}$ \\
\hline I4 & 34.0 & $2 \mathrm{I} \cdot 2$ \\
\hline 15 & 29.5 & I8.7 \\
\hline I4 & $32 \cdot 2$ & $15 \cdot \mathrm{I}$ \\
\hline 15 & $25^{\circ} 0$ & $7 \cdot 2$ \\
\hline 15 & 18.5 & $4 \cdot 6$ \\
\hline IO & $28 \cdot 2$ & $3 \cdot 6$ \\
\hline
\end{tabular}

\section{Table IX. Egg Production of Ripe Females kept in Unfiltered Sea Water, i95I}

\begin{tabular}{|c|c|c|c|c|c|c|c|c|c|c|c|c|}
\hline \multirow[b]{3}{*}{ Date begun } & \multirow{3}{*}{$\begin{array}{l}\text { No. of } \\
\text { Calanus }\end{array}$} & \multirow{2}{*}{\multicolumn{7}{|c|}{ Total no. of eggs laid on day }} & \multicolumn{4}{|c|}{ Omitting first day } \\
\hline & & & & & & & & & \multirow{2}{*}{$\begin{array}{c}\text { No. } \\
\text { laying }\end{array}$} & \multirow[b]{2}{*}{ Total no. } & \multirow{2}{*}{$\begin{array}{c}\text { Eggs per } \\
\text { batch }\end{array}$} & \multirow{2}{*}{$\begin{array}{l}\text { Eggs per } \\
\text { Calanus } \\
\text { per day }\end{array}$} \\
\hline & & I & 2 & 3 & 4 & 5 & 6 & 7 & & & & \\
\hline 2I. ii. 5 I & 20 & 270 & 7 & 2 & 33 & 20 & 7 & 一 & 7 & 69 & $20 \cdot 0$ & 0.7 \\
\hline 27. ii. $5 \mathrm{I}$ & I5 & 273 & I4 & I & 0 & o & 8 & 0 & 8 & 23 & $8 \cdot 0$ & 0.3 \\
\hline 6. iii. $5 \mathrm{I}$ & 15 & 366 & I56 & 63 & $3 I$ & IO & 5 & - & I4 & 265 & $20 \cdot 6$ & $3 \cdot 6$ \\
\hline 12. iii. $5 \mathrm{I}$ & 15 & 499 & $3 I$ & 82 & 25 & 12 & 8 & 25 & 9 & 183 & $17 \cdot 8$ & $2 \cdot 2$ \\
\hline 22. iii. $5 \mathrm{I}$ & 13 & 367 & I & I9 & 0 & 44 & II & 3 & 5 & 78 & $18 \cdot 5$ & $I \cdot I$ \\
\hline 23. iv. $5 \mathrm{I}$ & I5 & 512 & 77 & 62 & I60 & 44 & 66 & 72 & 14 & $48 I$ & $17 \cdot 7$ & $5 \cdot 7$ \\
\hline \multicolumn{13}{|l|}{ 3. v. 51: } \\
\hline Ist week & I4 & $68 \mathrm{I}$ & I56 & $55^{2}$ & 214 & I87 & 138 & I I I & I4 & 1358 & $3 I \cdot 3$ & $16 \cdot 2$ \\
\hline 2nd week & I4 & $6 I$ & 84 & 274 & 317 & 259 & $9 \mathrm{I}$ & I94 & 13 & 1280 & $24 \cdot 7$ & 13.9 \\
\hline 3rd week & II & II 7 & 82 & 157 & 27 & $5 \mathrm{I}$ & 25 & 47 & IO & 506 & $25 \cdot 5$ & 6.9 \\
\hline Three weeks & - & - & - & 一 & 一 & - & - & - & 一 & 3144 & $27 \cdot 4$ & $12 \cdot 6$ \\
\hline
\end{tabular}

$\star$ Numbers below 5 omitted.

In the experiment beginning on 3 May the first day is not omitted in the calculations for the second and third week. 
I95I: the shock of capture and examination seems to be enough. The presence or absence of food has no effect on the number of eggs or the number of females laying immediately after capture.

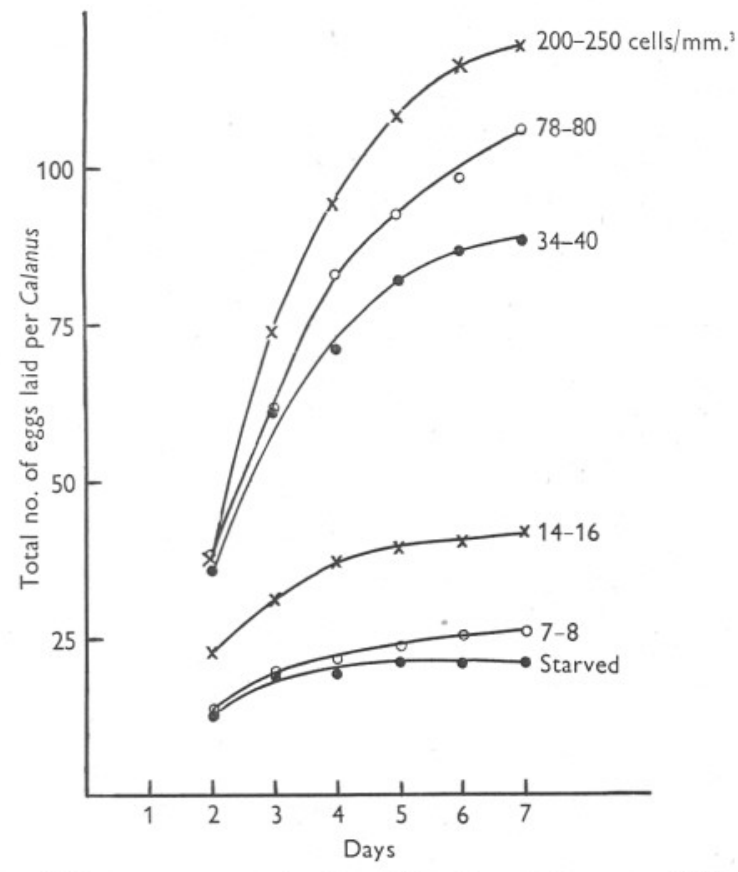

Text-fig. 3. Effect on egg production of feeding Calanus on Chlamydomonas cultures of different concentrations.

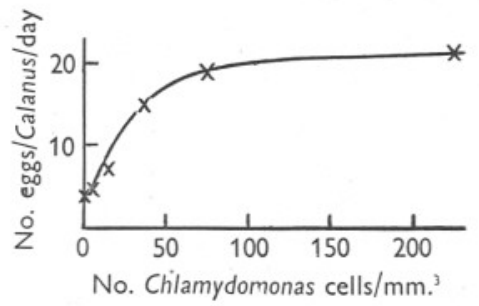

Text-fig. 4. Average number of eggs laid per day by Calanus fed on Chlamydomonas cultures of different concentrations.

The average number of eggs laid by a 'ripe' Calanus on the first night after being brought into the laboratory increased from January to March, as is shown in Text-fig. 5 and Table VIII. The increase was at first slow, but in both 1950 and I95I there was a steep rise in March and a subsequent fall. In I950 the maximum number (44.4) on I4 March can be related to a normal increase of Skeletonema, which by then had reached a figure of 340 cells $/ \mathrm{ml}$. 
In I95I the maximum egg number (4I) was not quite so high and corresponded to a much smaller increase of Chaetoceros and Coscinodiscus. After this the number laid per batch fell and it is possible that this is because the females were now laying in the sea. Calanus eggs were scarce in the sea on $2 \mathrm{March}$, there were a few on I4 March and considerable numbers were present on 20 March. The results suggest that until the middle of March the female is enlarging the eggs gradually but not necessarily laying them in the sea.

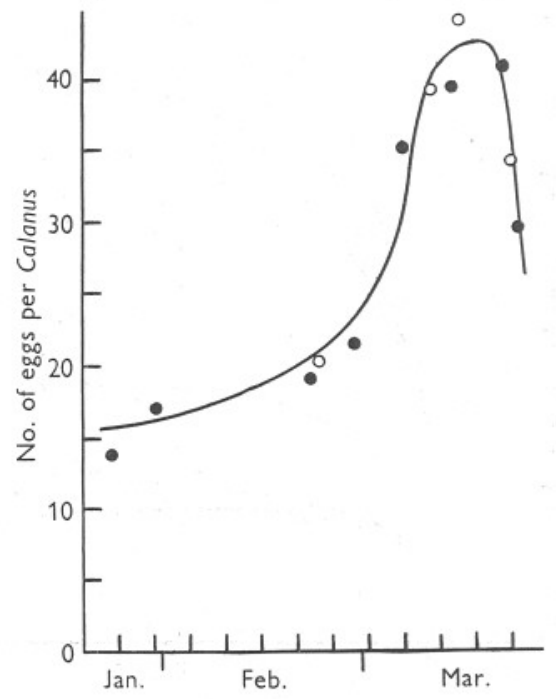

Text-fig. 5. Number of eggs per batch produced by Calanus during the spring. $\mathrm{O}, \mathrm{I} 950 ; \bullet, \mathrm{I} 95 \mathrm{I}$.

Table VIII. Average Number of Eggs in First Lay of Ripe CalanUS

\begin{tabular}{|c|c|c|c|c|c|}
\hline \multicolumn{6}{|c|}{ (Numbers under 5 omitted.) } \\
\hline Date & $\begin{array}{l}\text { No. of } \\
\text { Calanus }\end{array}$ & $\begin{array}{c}\text { Average no. } \\
\text { of eggs }\end{array}$ & Date & $\begin{array}{l}\text { No. of } \\
\text { Calanus }\end{array}$ & $\begin{array}{c}\text { Average no. } \\
\text { of eggs }\end{array}$ \\
\hline 22. ii. 50 & 5 & $20 \cdot 4$ & 2I. ii. $5 \mathrm{I}$ & $4 \mathrm{I}$ & $19 \cdot 0$ \\
\hline Io. iii. 50 & 25 & 39.2 & 27. ii. $5 \mathrm{I}$ & 60 & $2 \mathrm{I} \cdot 4$ \\
\hline I4. iii. 50 & 46 & $44 \cdot I$ & 6. iii. $5 \mathrm{I}$ & 29 & $35 \cdot 2$ \\
\hline 2 I. iii. 50 & 16 & $34 \cdot 3$ & 13. iii. $5 \mathrm{I}$ & 69 & $39 \cdot 4$ \\
\hline 24. i. $5 \mathrm{I}$ & 7 & $\begin{array}{l}1.5 \\
13.9\end{array}$ & 20. iii. $5 \mathrm{I}$ & 94 & $4 \mathrm{I}^{\circ} \mathrm{O}$ \\
\hline 30. i. $5 \mathrm{I}$ & II & I $7 \cdot \mathrm{I}$ & 22. iii. $5 \mathrm{I}$ & 69 & $29 \cdot 6$ \\
\hline
\end{tabular}

When the first generation reaches maturity the average number of eggs per batch rises again, and on 30 April-I May was $64 \cdot 2$.

During the experiments on different foods a number of ripe females was also kept in unfiltered sea water in the hope of finding out whether the sea during the spring diatom increase would become a medium as effective as the cultures used. Unfortunately the spring of I95 I was quite abnormal, and the enormous numbers of Skeletonema which usually appear in March did not come until May. Instead there was about the middle of March a much smaller 
increase in the numbers of Chaetoceros and Coscinodiscus and this was apparently sufficient to let the breeding of Calanus go on as usual.

In the laboratory the number of eggs laid in sea water (Table IX) was very low in February, rose a little in March and April but did not equal the cultures used until the first-generation females were laying during the Skeletonema increase in May. Until May the low numbers may have been caused partly by the small volume in which the Calanus were kept $-20 \mathrm{ml}$. changed every second day. Gauld (I95I) has shown that a Stage V Calanus can filter an average of about $70 \mathrm{ml}$. per day.

In May, therefore, fourteen Calanus were kept each in $50 \mathrm{ml}$. of water which was changed daily, and in the $2 \mathrm{I}$ days during which they were kept the egg production per Calanus varied from I87 to 422 . Towards the end of the 3 weeks egg production fell off considerably, although diatoms were still numerous in the sea water. In spite of this the females when examined on the 2Ist day mostly contained a number of large eggs apparently ready to lay. One of them is shown in Pl. Ic. The egg production per Calanus per day was I6.2 for the first week and 12.6 for the whole time, thus approaching the production by Calanus kept in Chlamydomonas culture.

The high egg production in these females (nine of the I I surviving laid over 250 eggs in the 2I days) shows that the figures given for the spermatophorebearing females (Text-fig. I) may well be equalled or exceeded by Calanus in the sea.

\section{Discussion}

It is interesting to consider the relation of these results to events in the sea.

When the over-wintering stock of Stage V comes to moult in the beginning of the year it does so with a good store of fat, in spite of having spent several months in diatom-poor water. It may be that the Calanus can find more food in winter than is supposed, or that its metabolism in winter is lower than during the rest of the year. That a lowered metabolism in winter may be an important factor is indicated by the results of several experiments comparing the food taken in by Stage $\mathrm{V}$ and female Calanus in the same culture of Chlamydomonas. On Io January, judging from the number of faecal pellets produced, the Stage V were eating less than half the amount that the females were. The experiment was repeated with the same results on 23 January and on I3 March; by 9 April, however, the new generation had appeared and Stage $\mathrm{V}$ was eating as much as, or more than, the females.

In 1950 the over-wintering Stage V Calanus began to moult in the end of December, and by the middle of February I95I most of the population consisted of adult females. On I February $53 \%$ of the females were immature and only $4 \%$ ripe, but the proportion of ripe increased gradually until on 5 March I \% was immature and $94 \%$ were ripe. Calanus eggs were scarce in the sea on 2 March, but considerable numbers of both eggs and nauplii were 
present on 20 March and the new generation grew up during the rest of March and April. Adult females of the new brood appeared on I2 April as immature and gradually replaced the over-wintering stock.

Nicholls (1933a) estimated from field work that a female after moulting takes about a month before the eggs are ready to lay. The egg-laying experiments, however, have shown that the time taken will depend very much on the food present in the sea. When given a plentiful supply an 'immature' female can lay eggs in 4 or 5 days and a 'semi-ripe' one in 2 or 3 , but the experiments with the females carrying spermatophores indicate that they do not often lay within a week after fertilization. The time taken from moulting up to this stage is uncertain and must depend partly on the stage of maturity at moult. The results with very immature females (p. 529) indicate a lapse of 2-3 weeks, but the fact that the proportion of immature females found in tow-nettings is low makes it more likely that the time is usually shorter. The fluctuating food conditions in the sea make it certain that the period from moulting to maturity will be longer than in the laboratory, and the dates given above for the increase in ripe females from 4 to $94 \%$ confirm Nicholls's estimate of about a month. The experiments also indicate that the life of a female may be considerably longer than has been hitherto supposed, for besides the 4 weeks or so taken to mature it may live at least another month laying successive batches of eggs.

The facts that the number of enlarging eggs in the female (judging from the numbers laid per batch) increases over a period of some weeks, and that during that time the eggs are scarce in the plankton indicate that the female does not need to lay eggs once they have matured but can retain them until the conditions are favourable. Unless food is present Calanus will lay only a few eggs in the sea; a large egg production will occur only with a diatom increase lasting some time. The actual stimulus to egg-laying and to the completion of the first maturation division which immediately precedes it is unknown. Food does not act as the immediate stimulus, but when available it seems to be rapidly digested and used for egg production.

The production of viable eggs after as much as 68 days by an isolated female Calanus is interesting in that it shows that a single fertilization is sufficient. In the sea males reach their peak of abundance before females and the percentage of females bearing spermatophores is highest early in the development of a generation. Only on rare occasions do the majority of females bear spermatophores. This is understandable when we remember that the spermatophore is carried for only I or 2 days, after which it drops off. When females are caught in the sea they are almost invariably fertilized, that is, the spermathecae are dark in colour and full of sperm. A few females were found with empty spermathecae, and some of these were kept in a dish with males but fertilization did not take place. Males do not live in captivity so well as females and copulation was never seen. 
The maximum total number of eggs laid by a single female (586) is much above the only previous estimate, over II2, which is that of Raymont \& Gross (I942). However, their Calanus may have laid before their observations began.

Not all feeding experiments resulted in egg production. With the possible exception of Coscinodiscus all the diatoms tried gave positive results. Other organisms were also successful, but perhaps more surprising is the complete failure of Hemiselmis and Chlorella. Chlorella is known to be difficult to attack because of its cellulose membrane, but on the same grounds it might have been expected that Chlamydomonas, which in fact gave very good results, would be difficult to digest. Raymont \& Gross (1942) found that Nitzschia closterium var. minutissima and Chaetoceros pseudocrinitus as well as several flagellates were eaten, although the Calanus survived better with the diatoms. The present observations extend and amplify their findings.

Nicholls (1933b) suggested that Calanus spawns at night, since eggs and young stages are always found above $30 \mathrm{~m}$., and this has now been confirmed for the over-wintering generation. The eggs are heavier than sea water, and the rate of sinking is given by Gross \& Raymont (I942) as $36 \mathrm{~m}$. in $24 \mathrm{hr}$. Since the minimum time of hatching is about $24 \mathrm{hr}$. the greatest depth at which the eggs will be found should be about $36 \mathrm{~m}$. In the results of Nicholls (I933a) and of Marshall et al. (I934) the vertical hauls were divided at 30 and $10 \mathrm{~m}$. respectively. When summed over the year the number of nauplii above and below Io $\mathrm{m}$. was approximately the same, but very few were found below $30 \mathrm{~m}$. The young copepodites do not show diurnal vertical migration (Nicholls, I933 $b$ ) and are confined to the surface layer so that the nauplii must swim up towards the surface. Since females show a marked diurnal vertical migration, the fact that the eggs are laid during the night ensures that they will be laid fairly near the surface. The first generation, which becomes adult towards the end of April and in May, is found near the surface during the day and lays throughout the $24 \mathrm{hr}$. However, those females of the first generation which live in deep water also lay throughout the $24 \mathrm{hr}$., and this is more difficult to understand. For if nauplii hatch below $50 \mathrm{~m}$. they will have a much longer way to swim up to the surface layers.

The suggestion that successive broods of Calanus depend on outbursts of diatom growth is supported by the evidence given here of the dependence of egg-laying on food. Although the experimental results show that food and egg-laying are closely connected, it does not follow that a food which will induce egg-laying will also be suitable for the feeding and development of the nauplii and early copepodite stages. Some preliminary work has shown, however, that even as large a diatom as Coscinodiscus centralis can be broken up and ingested by Copepodite Stage II, and that Peridinium trochoideum $(25 \times \mathrm{I} 9 \mu)$ can be eaten by at least Nauplius VI.

The production of broods by some of the smaller copepods also seems to 
depend on diatom outbursts (Marshall, 1949), and it may therefore be expected that these will show a similar effect of feeding on egg-laying.

We have pleasure in acknowledging the help given throughout the work by the staff of the Marine Station. We are very grateful to Dr Mary Parke of the Plymouth Laboratory for sending us cultures of all the organisms used.

\section{SUMMARY}

A description is given of female Calanus at different stages of maturity and of the process of egg-laying.

It has been observed that the eggs of the two forms of Calanus differ in size, those of helgolandicus being larger than those of finmarchicus. The former was scarce, about $4 \%$, in the over-wintering stock.

The females of the over-wintering stock of Calanus lay their eggs early in the morning, mainly between midnight and 3 a.m.; those of the first generation, which come to maturity in May, lay throughout the $24 \mathrm{hr}$.

The total egg production of individual females kept in the laboratory and fed has been found. The maximum was 586 eggs. Egg-laying may be spread over as much as 74 days and tends to occur in a series of bursts, each burst lasting for about a week. A single fertilization is enough for the whole of the egg-laying.

Egg production is largely dependent on the food available. When females are starved egg-laying ceases, but if they are fed again egg production begins too and is eventually not much less than in Calanus fed continuously.

A number of different cultures of diatoms and flagellates were tested as food, but it was found that not all of them resulted in egg production. All diatoms tested were successful. Inorganic material or a change in the reaction of the medium had no effect on egg production.

Calanus when kept in natural sea water produced only small numbers of eggs unless the water was rich in diatoms.

When brought into the laboratory ripe Calanus usually lay eggs overnight. The number thus laid was low in January and February and increased rapidly in March to a maximum of about 40 per batch. With the firstgeneration females much higher numbers were obtained.

The relation of these results to events in the sea is discussed. It is suggested that even when ripe a female Calanus can defer egg-laying until a suitable food supply is available. The spawning of Calanus in the sea should therefore coincide with diatom increases. 


\section{REFERENCES}

GAULD, D. T., I95I. The grazing rate of planktonic copepods. Fourn. Mar. Biol. Assoc., Vol. 29, pp. 695-706.

Gross, F. \& RAymont, J. E. G.,. I942. The specific gravity of Calanus finmarchicus. Proc. Roy. Soc. Edinb., B, Vol. 61, pp. 288-96.

Harding, J. P., Marshall, S. M. \& OrR, A. P., I95I. Time of egg-laying in the planktonic copepod Calanus. Nature, Vol. I67, p. 953.

Lowe, E., I935. On the anatomy of a marine copepod Calanus finmarchicus (Gunnerus). Trans. Roy. Soc. Edinb., Vol. 58, pp. 561-603.

LowndES, A. G., I943. Some applications of the displacement method of weighing living aquatic organisms. Proc. Zool. Soc. Lond., Vol. II3A, pp. $28-43$.

Marshall, S. M., I949. On the biology of the small copepods in Loch Striven. Fourn. Mar. Biol. Assoc., Vol. 28, pp. 45-I22.

Marshall, S. M., Nicholls, A. G. \& ORR, A. P., I934. On the biology of Calanus finmarchicus. V. Seasonal distribution, size, weight and chemical composition in Loch Striven in 1933 and their relation to the phytoplankton. Fourn. Mar. Biol. Assoc., Vol. 19, pp. 793-828.

NaIR, K. B., I939. The reproduction, oogenesis and development of Mesopodopsis orientalis Tatt. Proc. Indian Acad. Sci., B, Vol. 9, pp. 209-19.

— 1941. On the embryology of Squilla. Proc. Indian Acad. Sci., B, Vol. I4, pp. $543-76$.

Nicholls, A. G., I933a. On the biology of Calanus finmarchicus. I. Reproduction and seasonal distribution in the Clyde sea-area during 1932. Fourn. Mar. Biol. Assoc., Vol. 19, pp. 83-I Io.

- I $933 b$. On the biology of Calanus finmarchicus. III. Vertical distribution and diurnal migration in the Clyde sea-area. Fourn. Mar. Biol. Assoc., Vol. 19, pp. $139-64$.

Raymont, J. E. G. \& Gross, F., I942. On the feeding and breeding of Calanus finmarchicus under laboratory conditions. Proc. Roy. Soc. Edinb. B, Vol. 6I, pp. $267-87$.

REES, C. B., I949. The distribution of Calanus finmarchicus (Gunn.) and its two forms in the North Sea, 1938-39. Hull Bull. Mar. Ecol., Vol. 2, pp. 215-75.

Russell, F. S., I95I. A re-examination of Calanus collected off Plymouth. Fourn. Mar. Biol. Assoc., Vol. 30, pp. 313-I4.

Ussing, H. H., I938. The biology of some important plankton animals in the fjords of East Greenland. Medd. om Gronland, Bd. I00, pp. I-I08.

WIBORG, K. F., I940. The production of zooplankton in the Oslo fjord in I933-I934 with special reference to the copepods. Hvalraidets Skrifter, No. 2I, 85 pp.

WIMPENNY, R. S., I937. The distribution, breeding and feeding of some important plankton organisms of the south-west North Sea in 1934. Part I. Fish Invest., Ser. II, Vol. I5, No. 3, pp. I-53. 


\section{EXPLANATION OF PLATE I}

A. Female Calanus with ovary in medium state. The diverticula from the genital ducts fill only part of the head end. B. Female Calanus with ovary in ripe state. Large eggs are seen filling the diverticula in the head end and along the course of the oviducts. c. Female Calanus with ovary in ripe state. This Calanus has already laid many eggs and they are not so crowded as in B, but one row of large eggs is visible. D. Calanus in the process of laying eggs which have not yet begun to round off. E. The same Calanus slightly later. The same groups of eggs can be traced and the earlier laid are rounding off. F. A later stage in egg-laying. Some of the eggs are now spherical. 


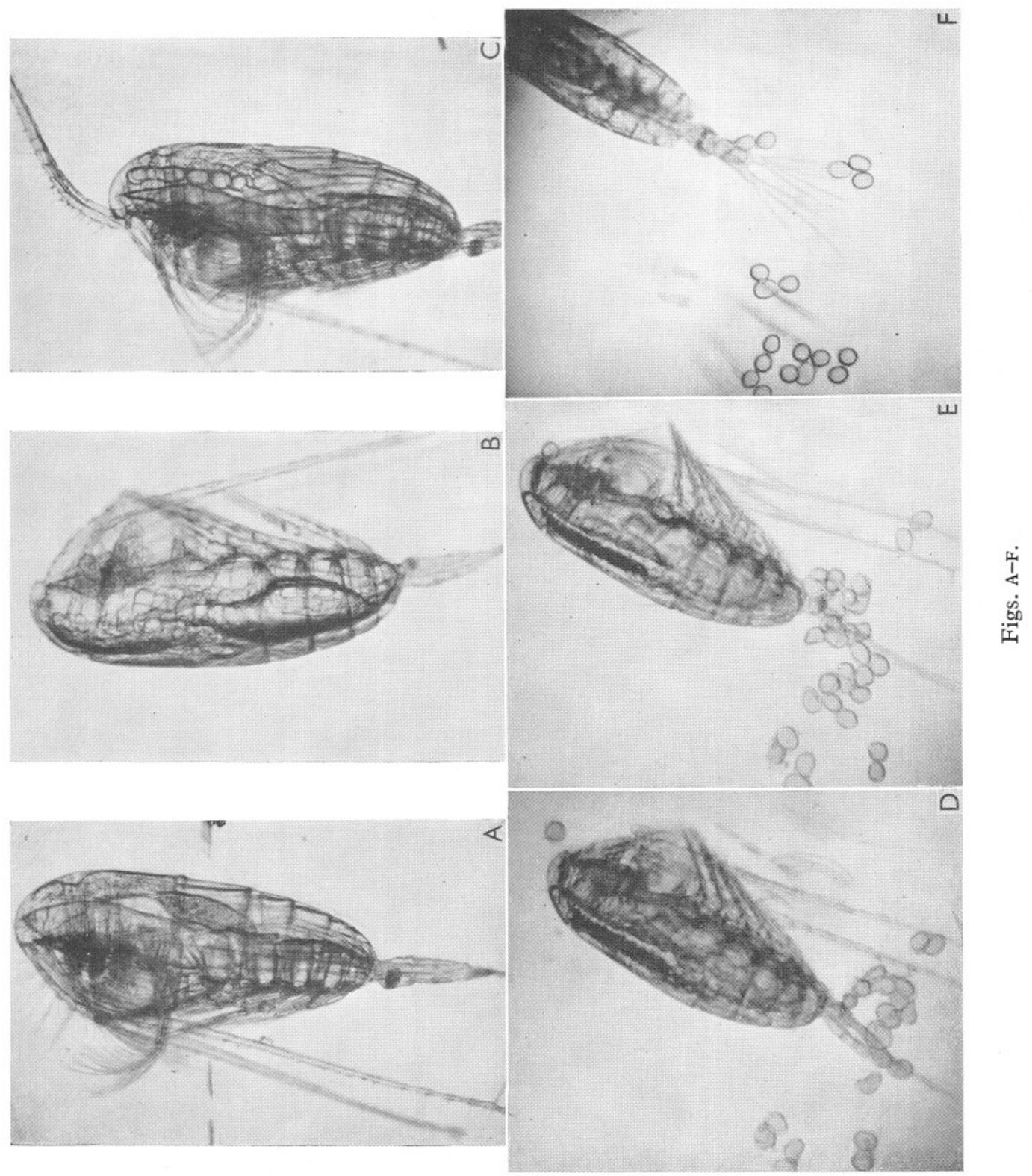

